\title{
Kebenaran Materil dalam Kajian Hukum Pidana
}

\author{
Johari ${ }^{1}$ \\ Dosen Fakultas Hukum Universitas Malikussaleh
}

\begin{abstract}
Abstrak
Karya ini merupakan studi pustaka tentang kebenaran materil dalam hukum pidana. Sebuah peradilan melibatkan terdakwa, saksi, pengacara, jaksa dan hakim. Interaksi antara tokoh-tokoh inilah yang akan menentukan apakah seorang terdakwa dalam suatu kasus hukum dinyatakan bersalah atau tidak. Apakah suatu kasus hukum dianggap sebagai suatu perbuatan melanggar hukum sangat ditentukan oleh persepsi hakim terhadap kasus hukum itu. Putusan-putusan yang diberikan pada dasarnya adalah hasil dari fakta dan keyakinan hakim yang rasiologis, meskipun sering dalam kenyataan sulit untuk menakar atau mengukur kepuasan para pihak, mengingat korban tidak pernah diminta pendapatnya oleh jaksa, mengingat perkara yang terjadi sudah lampau sehingga diragukan nilai keaslian suatu peristiwa pidana bisa berpindah dalam suatu sidang pengadilan, sehingga dikhawatirkan dan diragukan tentang keadilan yang diterapkan. Dalam tulisan ini, penulis mengkaji tentang bagaimana semestinya kebenaran materil yang diinginkan dalam hukum pidana yang berlaku di Indonesia. Karya ini adalah kajian yuridis normatif dengan pendekatan kualitatif. Data-data yang tertuang dalam karya ini diambil dari berbagai sumber hukum yang relavan. Hasil penelitian menunjukkan bahwa hukum pidana yang berlaku di Indonesia telah memberikan batasan dan jalan kepada penegak hukum untuk menemukan kebenaran materil.
\end{abstract}

Kata Kunci: Hakim, Kebenaran Materil, Hukum Pidana 


\section{A. PENDAHULUAN}

Tulisan ini saya mulai dengan mengutip ungkapan seorang ahli hukum terkenal dari Philipina, Dr. Salvador Laurel, "You have shown me the sky to a creature who will never do better than crawl" (Anda memperlihatkan langit kepadaku, tapi apalah artinya cakrawala, bagi manusia kecil melata, yang hanya mampu merangkak terseok seok). (M. Yahya Harahap :2009).

Jelas bahwa ada semangat yang sangat positif dan kepuasan yang luar biasa bagi pembentuk Undang undang Nomor 8 Tahun 1981 Tentang Kitab Undang-undang Hukum Acara Pidana (KUHAP), sehingga dianggap sebagai karya agung bangsa Indonesia, hal ini tidak berlebihan memang bila dilihat dari sejarah masa lalu sebelum tahun 1981, bangsa ini masih menggunakan HIR 1941 (het Herziene Inlandsch Reglement) sebagai hukum acaranya yang merupakan sisa dari pemerintahan Hindia Belanda yang diyakini beroposisi dengan hak asasi manusia.

Bila kita melihat keseluruhan isi dari KUHAP, sangat memberi perhatian pada penghormatan terhadap hak tersangka dan terdakwa, sehingga seakan akan penegak hukum dihambat geraknya dan diposisikan tidak bisa menyentuh tersangka tanpa sesuai due process of law. Bahwa penegakan hukum adalah serangkaian tindakan dari berbagai sub sistem dari sistem peradilan pidana yang saling terkoneksi melaksanakan tugasnya sesuai differensiasi fungsional dari masing masing lembaga.

Kebenaran materiel yang dimaksudkan adalah kebenaran yang seimbang antara hukuman dan kesalahan, yang takaran hukuman sesuai dengan ketercelaan dari sifat jahat dari sebuah perbuatan, dengan mempertimbang segala hal ikhwal sehingga suatu tindak pidana itu terjadi,- sesuai dengan pendapat dari Prof. Mardjono Reksodiputro, S.H.,M.A, yang menyebutkan bahwa sistem peradilan pidana adalah sistem pengendalian kejahatan yang terdiri dari lembaga kepolisian, kejaksaan, pengadilan dan pemasyarakatan terpidana. Dalam kesempatan lain, Mardjono 
mengemukakan bahwa sistem peradilan pidanan adalah sistem dalam suatu masyarakat untuk menanggulangi masalah kejahatan. Menanggulangi diartikan sebagai mengendalikan kejahatan agar berada dalam batas-batas toleransi masyarakat..

(Mardjono

Reksodipuro: 1997). Termasuk juga adanya keseimbangan yang diberikan oleh negara dan kesadaran penuh dari si tersangka/terdakwa tentang apa yang akan dihadapinya sehingga bisa mempersiapkan dirinya dengan baik dalam melakukan pembelaannya.

Untuk mencapai seperti yang disebutkan diatas, oleh KUHAP hal tersebut telah diakomodir sedemikian rupa,-walaupun akhirnya kita sadari KUHAP juga masih banyak dijumpai kelemahan yang harus segera direvisi, namun kehadiran KUHAP dianggap sebagai langkah maju dibandingkan HIR pada jaman dulu.

Kebenaran materiel adalah kebenaran yang sebenarnya, kebenaran yang hakiki yang sebenarnya tidak bisa dijumpai di muka bumi ini, kebenaran tersebut hanya ada di langit, namun setidaknya walaupun kita manusia tidak bisa menyamainya, tapi setidak-tidaknya mendekati kebenaran hakiki tersebut, dan itu sebagai ikhtiar kita manusia, yang dalam konteks ini adalah benar secara substansial dan benar secara prosedural.

Masalah hukum adalah masalah manusia, pelanggaran hukum dan penegakan hukum adalah pekerjaan yang dilakukan oleh manusia. Oleh karena itu hukum tidak bisa dilihat hanya dari ketentuan yang tertulis dalam pasalpasal hukum dan perundangundangan. Penerapan sebuah peraturan hukum sangat dipengaruhi oleh banyak variabel psikologis pihak-pihak yang terkait dengan hukum itu sendiri.

Sebuah peradilan melibatkan terdakwa, saksi, pengacara, jaksa dan hakim. Interaksi antara tokoh-tokoh inilah yang akan menentukan apakah seorang terdakwa dalam suatu kasus hukum dinyatakan bersalah atau tidak. Apakah suatu kasus hukum dianggap sebagai suatu perbuatan melanggar hukum sangat ditentukan oleh persepsi hakim terhadap kasus 
hukum itu. Persepsi ini paling sedikit diwarnai oleh persepsi terhadap perilaku pelanggar hukum dan penafsiran terhadap kalimat hukum yang tertulis dalam peraturan hukum (Yusti Probowati Rahayu:2005).

Dalam lintas sejarah penanganan perkara pidana dalam peradilan di Indonesia, persoalan pemidanaan menjadi perhatian banyak kalangan, khususnya para pencari keadilan. Para pencari keadilan adalah orang yang terpaksa berurusan dengan hukum karena sesuatu dan lain hal, yang mereka itu awam dengan hal yang sedang dihadapinya. Mereka para pencari keadilan berharap keadilan didapatkan,-tidak dalam pemahaman keadilan yang diberikan, karena keadilan adalah suatu keniscayaan yang menjadi hak setiap manusia, dan oleh karena itu menjadi kewajiban bagi setiap orang untuk menghormatinya dan memenuhinya.

Para justiable berada dalam posisi tidak menguntungkan, menderita baik secara fisik maupun psikis, baik materil maupun nonmateril. Penderitaan mereka menjadi beban dan tanggungan masyarakat, dalam hal ini negara menjembatani kepentingan akan kebutuhan rasa aman dalam hidup, melalui jaksa penuntut umum harapan itu dititipkan. Namun kondisi korban yang riil tidak bisa dituangkan sepenuhnya dalam bentuk dakwaan, sebab bukan jaksa yang menjadi korban, jaksa hanya menakar tingkat kerugian korban dari penilaian atau anggapan pantas atau tidak pantas, tercela atau tidak tercela dari sebuah perbuatan, yang kemudian dirumuskan menjadi norma dalam bentuk undang-undang. Selain itu kecenderungan perhatian terhadap korban biasanya terabaikan dengan lebih memfokuskan pada pelaku atau tersangka.

Hakim pun memeriksa perkara sesuai dengan apa yang didakwakan, sehingga kesan hakim sebagai corong undang-undang benar adanya. Putusan-putusan yang diberikan adalah hasil dari fakta dan keyakinan hakim yang rasiologis, namun sering dalam kenyataan adalah susahnya menakar atau mengukur kepuasan para pihak, mengingat korban tidak pernah diminta pendapatnya oleh jaksa, 
mengingat perkara yang terjadi sudah lampau sehingga diragukan nilai keaslian suatu peristiwa pidana bisa berpindah dalam suatu sidang pengadilan, sehingga dikhawatirkan dan diragukan tentang keadilan yang diterapkan.

\section{B. IDENTIFIKASI MASALAH}

Dari uraian diatas kiranya menarik untuk dikaji lebih lanjut tentang kelemahan kita dalam berhukum yang sangat berpotensi melahirkan putusan yang salah, sehingga merugikan masyarakat dalam mencari keadilan.

Penelitian ini menggunakan pendekatan yuridis normatif, yaitu memberikan tanggapan atas cara cara kita dalam berhukum, yang telah secara prosedural diatur dalam KUHAP, dan diharapakan diterapkan dengan benar sehingga didapati kebenaran substansial. Jenis penelitian ini adalah kualitatif, yaitu penelitian yang berfokus pada kualitas dari sebuah isu hukum yang diangkat, dalam hal ini tentang apa yang seharusnya dilakukan oleh penegak hukum dalam ikhtiarnya memutus suatu perkara pidana, menuju kebenaran materiel, namun selalu menginsafi bahwa dia berserah diri kepada Tuhan sang Maha Adil, karena telah bersumpah " DEMI KEADILAN". Sifat penelitian ini deskriptif, memaparkan dan menggambarkan persoalan yang terjadi dalam cara cara kita berhukum, karena semua orang menunggu keadilan, baik korban maupun pelaku. Hukum yang baik, cara berhukum yang baik, adalah langkah memperkecil kesesatan dalam putusan.

\section{PEMBAHASAN}

\section{Keadilan Proseduran dan Keadilan Substansial}

Sebelum menjawab rumusan masalah, akan terlebih dahulu penulis paparkan konsep keadilan dan dimana keadilan di dapatkan? Keadilan di definisikan sebagai keselarasan atau kepatutan. Ibnu Khaldun menyatakan bahwa " justice is something familiar requeires harmony in the world", oleh karenanya "justice must be seen to be done in order to create on orderly and harmonious society". Dalam hal ini Ibnu Khaldun mengatakan bahwa dalam melihat permasalahan keadilan 
dan hukum pidana, ia memandang keadilan sebagai sesuatu yang dapat diterima oleh semua orang, karena setiap orang memiliki posisi dalam menentukan keputusan (Eva Achjani Zulfa:2009).

Dalam konteks negara di masa tradisional (baca lampau), keadilan dipraktekkan oleh masyarakat yang pengadilannya jauh bersifat alami. Pengadilan muncul secara alami dari kebutuhan masyarakat yang tidak dibatasi oleh berbagai macam pengaturan dan prosedur. Pengadilan dimasa lalu merupakan bangunan sosiologis yang bersifat total. Pengadilan sangat dekat dengan masyarakat, bahkan seperti masyarakat itu sendiri. Oleh Max Weber, tipe peradilan seperti itu disebutnya Khadi Justice, yaitu suatu peradilan yang tidak berorientasi kepada ' fixed rules of formaly rational law', tetapi kepada hukum substantif yang bertolak dari postulatpostulat etika, religi, politik dan lainlain pertimbangan kemanfaatan.

Baru kemudian seiring dengan kehadiran negara modern, pengadilan muncul sebagai hasil rancangan artifisial yang rasional seperti sekarang ini, yang mewajibkan para hakim memutus berdasarkan 'fixed rules of rational formal law'. Dengan menjadi bangunan yang dirancang secara khusus itu pengadilan modern makin jauh sifatnya dari suatu institusi sosiologis yang alami.

Pengadilan menjadi institusi modern yang dirancang secara spesifik bersamaan dengan munculnya negara modern di sekitar abad 18. Negara modern bertumpu pada pembagian rasional antara bidang-bidang legislasi, yudikasi, dan eksekutif. Rancangan rasional tersebut menjadikan pengadilan dan pekerjaan mengadili sebagai proses yang diatur dengan prosedur yang jelas dan transparan, maka pekerjaan mengadili tidak lagi hanya bersifat mengadili secara substansial, melainkan juga berupa penerapan dari prosedur yang ketat. Pengadilan boleh dikatakan sebagai suatu badan yang memutuskan keadilan berdasarkan aturan dan prosedur yang sudah ditentukan. Maka sejak saat itu pula kita berbicara tentang adanya dua macam keadilan, yaitu keadilan substansial (substantial justice) dan keadilan formal (formal justice atau 
legal justice). Pada masa lampau, pembedaan seperti itu tidak ada, oleh karena tidak ada peraturan yang kompleks yang mengatur bagaimana putusan pengadilan diberikan. Pada waktu itu mengadili adalah memberikan putusan secara substansial (Satjipto Rahardjo:2010).

Kasus kasus yang ada membuktikan betapa Hakim pun manusia biasa dari darah dan daging. Manusia merupakan campuran antara iblis dan malaikat dengan takaran yang berbeda-beda. Keinsafan tentang ketidaksempurnaan manusia seyogyanya mendorong kita untuk lebih memperjuangkan hak-hak asasi manusia, dan menjauhi lubang-lubang yang mungkin menjerumuskan kita kepada kesesatan peradilan.

Dibalik hidup yang teramat fana ini, dengan segala kelemahan hati dan tubuh kita, menanti mahkamah Sang Maha Adil yang tak dapat diakali, disuap, atau dihindari, hal itu hendaklah mendorong kita untuk mengikhtiarkan keadilan hukum bagi setiap warga negara Republik yang dilahirkan oleh suatu perjuangan menentang ketidakadilan kolonial dan perkosaan hak-hak asasi manusia.

\section{Pertimbangan Hakim dalam}

\section{Menjatuhkan Pidana}

Secara yuridis, seorang hakim dalam hal menjatuhkan pidana kepada terdakwa tidak boleh menjatuhkaan pidana tersebut kecuali apabila dengan sekurang-kurangnya dua alat bukti yang sah, sehingga hakim memperoleh keyakinan bahwa suatu tindak pidana benar-benar terjadi dan terdakwalah yang bersalah melakukannya (Pasal 183 KUHAP).

Dalam Pasal 184 KUHAP, disebutkan, Alat bukti sah yang dimaksud adalah:

(a). Keterangan Saksi;

(b). Keterangan Ahli;

(c). Saksi;

(d). Petunjuk;

(e).Keterangan Terdakwa

Putusan hakim merupakan puncak dari suatu perkara yang sedang diperiksa dan diadili oleh seorang hakim. Hakim memberikan keputusannya mengenai hal-hal sebagai berikut:

1) Keputusan mengenai peristiwanya, apakah terdakwa telah melakukan 
perbuatan yang dituduhkan kepadanya,

2) Keputusan mengenai hukumnya, apakah perbuatan yang dilakukan terdakwa itu merupakan suatu tindak pidana dan apakah terdakwa bersalah dan dapat dipidana,

3) Keputusan mengenai pidananya, apabila terdakwa memang dapat dipidana.

Hakim dalam menjatuhkan pidana juga menggunakan pertimbangan yang bersifat yuridis ataupun non yuridis. Pertimbangan yang bersifat yuridis adalah pertimbangan hakim yang didasarkan pada faktor-faktor yang terungkap di dalam persidangan dan oleh undangundang telah ditetapkan sebagai hal yang harus dimuat di dalam putusan. Pertimbangan yang bersifat yuridis di antaranya:
a) Dakwaan jaksa penuntut umum,
b) Tuntutan pidana,
c) Keterangan saksi,
d) Keterangan terdakwa,
e) Barang-barang bukti,
f) Pasal-pasal dalam Undang-Undang Tindak Pidana .

Selain pertimbangan yang bersifat yuridis hakim dalam menjatuhkan putusan membuat pertimbangan yang bersifat non yuridis. Pertimbangan yuridis saja tidaklah cukup untuk menentukan nilai keadilan misalnya dalam memutus pengurangan sanksi pidana terhadap terdakwa yang mengembalikan kerugian dalam tindak pidana korupsi tanpa ditopang dengan pertimbangan non yuridis yang bersifat sosiologis, psikologis, kriminologis dan filosofis.

Fungsi utama dari seorang hakim adalah memberikan putusan terhadap perkara yang diajukan kepadanya, dimana dalam perkara pidana hal itu tidak terlepas dari sistem pembuktian negatif (negative wetterlijke), yang pada prinsipnya menentukan bahwa suatu hak atau peristiwa atau kesalahan dianggap telah terbukti, disamping adanya alat-alat bukti menurut undangundang juga ditentukan keyakinan 
hakim yang dilandasi dengan integritas moral yang baik.

\section{Kesimpulan}

Manusia bukan saja tak lupat dari kekhilafan dan kekeliruan, melainkan justru merupakan sumber kedua sifat itu, dan seorang hakim yang juga manusia tidak selalu menyadari telah melakukan kesalahan. Kekeliruan dan keluputan ingatan para saksi, prasangka, dan praanggapan mereka, dapat mengakibatkan hukuman dan penderitaan terhadap seorang tergugat. Bahkan kekhilafan itu bisa menggiring tergugat ke tiang gantungan atau ke muka regu tembak. Sebab, bukannya jarang diketahui dan disadarinya suatu kekeliruan putusan peradilan kadangkadang datang pada saat yang sangat terlambat-ketika tersangka telah terlanjur dihukum mati tanpa salah, padahal hidup manusia hanya sekali dan tak terulang/einmalig (Hermann Mostar:1987).

Pengadilan adalah benteng terakhir bagi pencari keadilan, begitu sering kita dengar, karena memang pada hakimlah pencari keadilan menitip harapan. Sidang pengadilan yang bebas dan hakim yang tidak berpihak bisa mewujudkan kebenaran materiel, kebenaran yang adil dan layak.

\section{DAFTAR PUSTAKA}

Hermann Mostar, 1987, Peradilan

Yang Sesat, Terjemahan dan

Penerbit Oleh PT. Pustaka

Utama Grafiti, Jakarta.

Mardjono Reksodiputro, 1997, Bunga Rampai Permasalahan Dalam Sistem Peradilan Pidana, Kumpulan Karangan Buku Kelima, Pusat Pelayanan Keadilan dan Pengabdian Hukum, Universitas Indonesia, Jakarta.

Satjipto Rahardjo, 2010, Sosiologi Hukum, Perkembangan Metode dan Pilihan Masalah, Genta Publishing, Yogyakarta. M. Yahya Harahap, 2009, Pembahasan Permasalahan dan Penerapan KUHAP, Penyidikan dan Penuntutan, Sinar Grafika, Jakarta.

Yusti Probowati Rahayu, 2005, Dibalik Putusan Hakim, 
Kajian Psikologi Hukum

Dalam Perkara Pidana,

CV.Citramedia, Sidoarjo 